\title{
SUSTAINABILITY OF PALM OIL AND ITS ACCEPTANCE IN THE EU
}

\section{OOSTERVEER, $\mathbf{P}^{*}$}

\begin{abstract}
Palm oil is highly controversial within the European Union (EU) as is illustrated by regular items in public media and decisions by the European institutions, such as the European Parliament. Producing countries are hardly engaging in these public and political debates but their participation is essential to develop an effective sustainable palm oil strategy. This article reviews the recent and current debates within the EU on palm oil use for biofuels and for food and other purposes. It proves important to distinguish between these two different goals because their governance dynamics within the EU are completely different. The biofuels market is dominated by government institutions while the market for food and industrial goods is dominated by private companies and private governance initiatives. Engagement of producing countries is likely to have little impact on the EU's biofuels policy. More opportunities exist in the market for food and other purposes, provided attention is being paid to legitimacy and accountability of producing countries' engagement.
\end{abstract}

Keywords: European Union, biofuels, sustainability.

Date received: 5 August 2019; Sent for revision: 18 August 2019; Accepted: 27 January 2020; Available online: 28 July 2020.

\section{INTRODUCTION}

In recent years, palm oil is increasingly becoming controversial, especially in public and political debates within the European Union (EU). Palm oilbased biofuels in particular are drawing criticisms from non-governmental organisations (NGO) calling for a boycott, while several Parliaments in Europe have even voted for excluding palm oil from the European biofuel market (Novelli, 2016). These controversies are generally little understood in palm oil producing countries such as Indonesia and Malaysia. Some observers in these countries consider the debate on sustainable palm oil in Europe rather as a strategy to promote the interests of European vegetable oil producers while others see it as an attempt to impose Western environmental values on Asian countries (Pye, 2019). Further exploring this debate and uncovering the background of the

\footnotetext{
Environmental Policy Group,

Wageningen University and Research,

Hollandseweg 1, Wageningen 6706AX,

The Netherlands.

E-mail: peter.oosterveer@wur.nl
}

European views on palm oil is important in order to increase the opportunities for dialogue on the future role of palm oil as a sustainable source of food and an input for biofuel and other industrial processes involving also the producing countries.

This article reviews the controversies surrounding the production, use and trade of palm oil in order to better understand the critical views. The article is primarily based on a literature review on the EU biofuel policy (Koning, 2019), supplemented with additional literature to provide the necessary background. This article starts with giving an overview of global palm oil trade and the $\mathrm{EU}$ and gives basic information about the role of palm oil in the EU biofuels production. Next, the EU policy on biofuels will be elucidated with particular attention for palm oil as a feedstock, followed by a review of the EU policy on other usage of palm oil. This overview provides the basis for an analysis of the criticisms expressed in European public and political debates. These comments are further discussed to assess their relevance for palm oil producing countries. Finally, this article ends with the main conclusions. 


\section{THE WORLD OF GLOBAL PALM OIL TRADE}

Palm oil is a vegetable oil and used for many food and non-food purposes, such as energy, feed, chemicals and detergents. Its use is increasing in recent decades because applying vegetable oil in general is growing considerably, while therein the relative contribution from palm oil is rising as well. Global use of vegetable oil has increased from 72 million tonnes in 1995 to 207.5 million tonnes in 2019 (Mielke, 2018) and https: / / www.statista.com / statistics / 263978/global-vegetable-oil-productionsince-2000-2001/. In the mix of different vegetable oils, palm oil has replaced soyabean oil as the leading oil and now represents a share of more than $35 \%$ of the global vegetable oil market. Palm oil's success on the international market is explained by its price, which as Bentivoglio et al. (2018a) show, is generally slightly lower than for other vegetable oils, and by its versatility in use (Aguiar et al., 2018). As a consequence, palm oil production, trade and use are going through a rapid phase of expansion. Global palm oil use grew from 14.6 million tonnes in 1995 to 61.1 million tonnes in 2015 (Figure 1). Palm oil production has increased with nearly $30 \%$ over the period 2015 until 2019 (Figure 2). Over the same period, global exports have increased with some $25 \%$ (Figure 3).

These figures show that palm oil is a highly traded commodity as some $70 \%$ of its global production is actually traded internationally and that this global trade is still expanding. The main producers and exporters of palm oil are found in South-east Asia, with Indonesia being the largest producer and exporter of palm oil, closely followed by Malaysia (Table 1). Together, Indonesia and

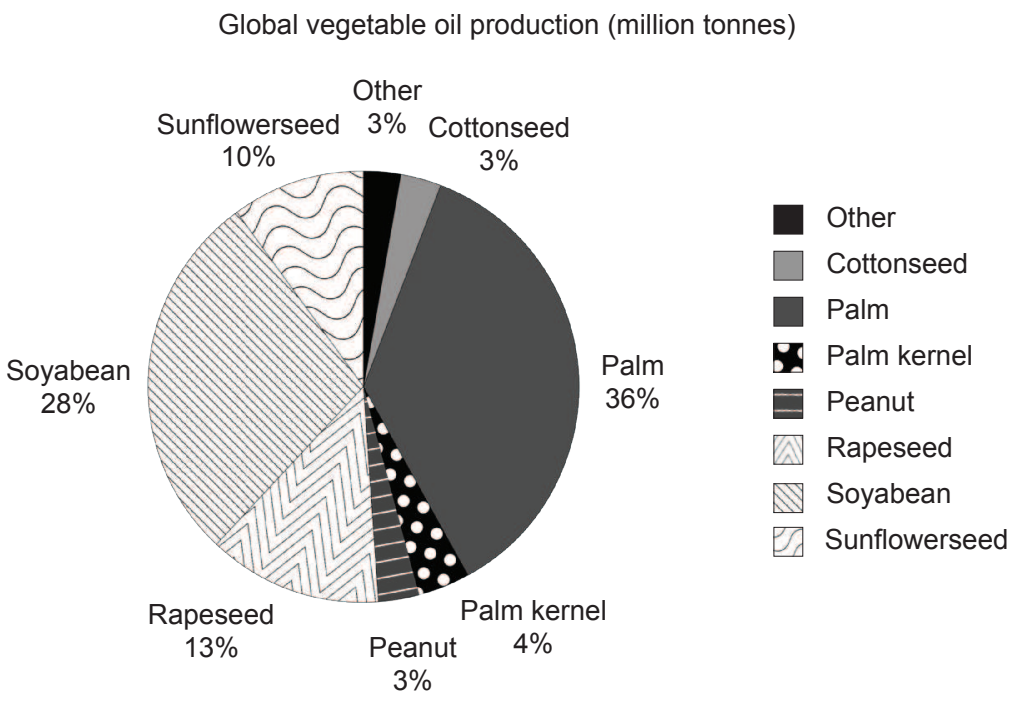

Source: USDA (2019).

Figure 1. Composition global vegetable oil production in 2019.

(t) Annual production palm oil (1000 t)

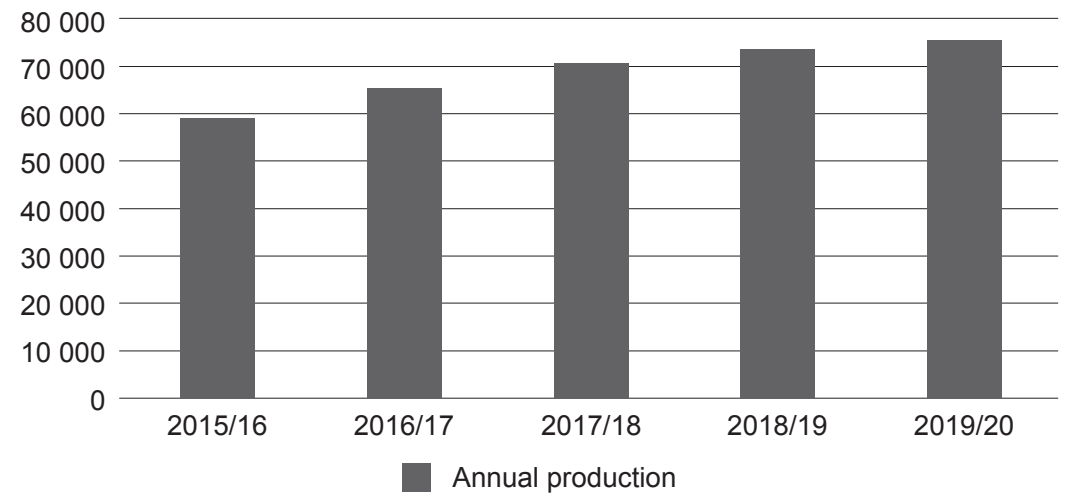

Source: USDA (2019).

Figure 2. Annual palm oil production. 


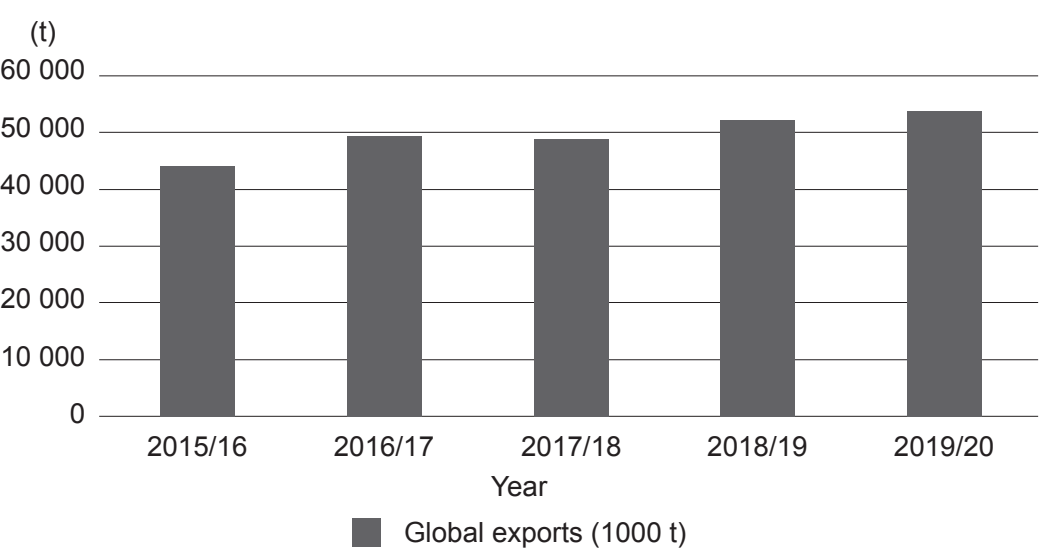

Source: USDA (2019).

Figure 3. Global palm oil exports.

(t)

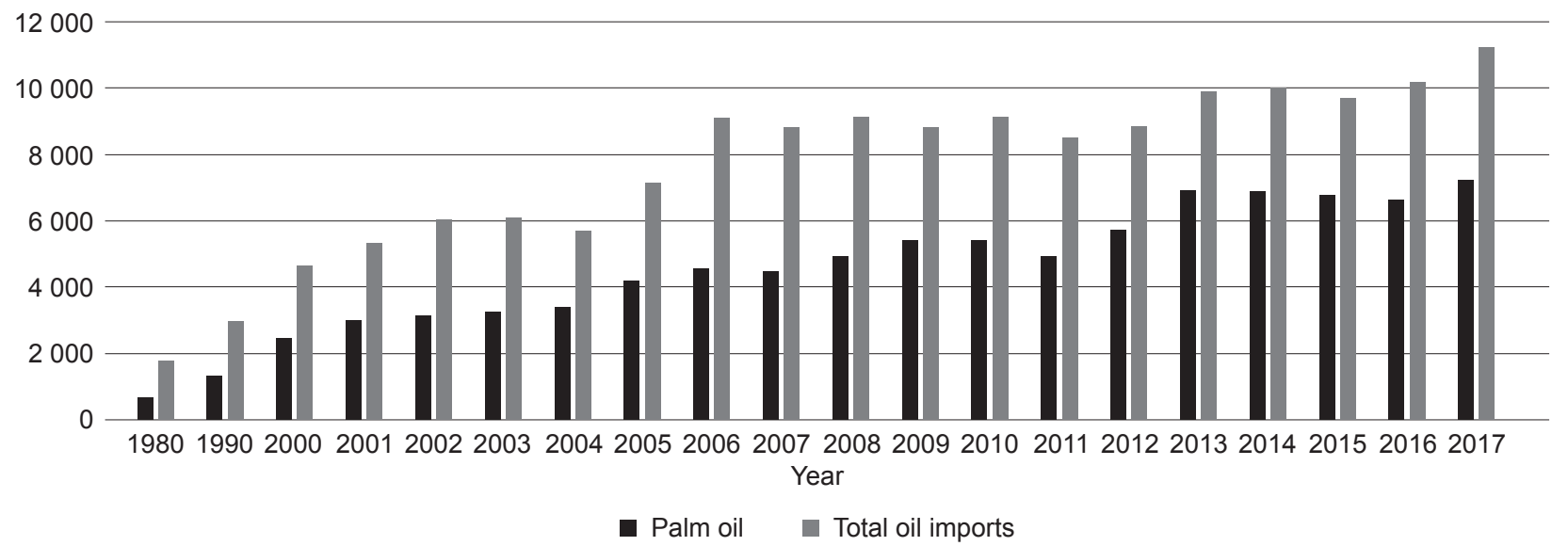

Source: Fediol (2019).

Figure 4. European Union (EU) palm oil imports (1980-2017) (in 1000 t).

Malaysia are responsible for over $90 \%$ of global palm oil exports (Table 2). The list of large importers is somewhat larger with India being the largest one, followed by the EU and then China. Other countries are importing much lower quantities of palm oil (Table 3).

TABLE 1. TOP FIVE PALM OIL PRODUCERS IN 2019/2020

\begin{tabular}{clc}
\hline Rank & \multicolumn{1}{c}{ Country } & $\begin{array}{c}\text { Production } \\
(\mathbf{1 ~ 0 0 0 ~ t )}\end{array}$ \\
\hline 1 & Indonesia & 43000 \\
2 & Malaysia & 20700 \\
3 & Thailand & 3000 \\
4 & Colombia & 1680 \\
5 & Nigeria & 1015 \\
\hline
\end{tabular}

Source: USDA (2019).

TABLE 2. TOP FIVE PALM OIL EXPORTERS IN 2019/2020

\begin{tabular}{clc}
\hline Rank & \multicolumn{1}{c}{ Country } & $\begin{array}{c}\text { Production } \\
(\mathbf{1} \text { 000 } \mathbf{~})\end{array}$ \\
\hline 1 & Indonesia & 30000 \\
2 & Malaysia & 18000 \\
3 & Guatemala & 815 \\
4 & Colombia & 720 \\
5 & Papua New Guinea & 635 \\
\hline
\end{tabular}

Source: USDA (2019).
TABLE 3. TOP FIVE PALM OIL IMPORTERS IN 2019/2020

\begin{tabular}{clc}
\hline Rank & \multicolumn{1}{c}{ Country } & $\begin{array}{c}\text { Production } \\
(\mathbf{1 ~ 0 0 0 ~})\end{array}$ \\
\hline 1 & India & 10750 \\
2 & European Union & 6950 \\
3 & China & 6700 \\
4 & Pakistan & 3300 \\
5 & Bangladesh & 1850 \\
\hline
\end{tabular}

Source: USDA (2019).

The EU is following India as the largest importer of palm oil and has been importing palm oil already for many years as an input in the European food and processing industries. As Figure 4 illustrates, vegetable oil imports in the EU have increased substantially since 1980 with a growing proportion originating from palm oil.

In recent years an increasing proportion of the imported palm oil is being used for biofuel production in the EU, replacing soyabean oil as the main imported feedstock for biodiesel. In 2015, 3.35 million tonnes of palm oil was used as feedstock for biodiesel in the EU (Mielke, 2018). About 46\% of all palm oil imported to the EU in that year was used for biofuel production, while 9\% was used for 
electricity and heating and $45 \%$ for food, animal feed and industrial use (Copenhagen Economics, 2018).

The growing demand for palm oil in the EU has contributed to very heated debates, in media and political arenas, about the sustainability of palm oil and its production. A range of different sustainability-related problems associated with palm oil production and use figure in these debates, such as deforestation, in particular the destruction of rainforests (Austin et al., 2019), the threat to biodiversity in general and in particular the habitat destruction of threatened species such as the orang utan and the Sumatran tiger, the contribution to climate change through forest clearing and the use of peatlands, the health problems caused by the haze from fires clearing the forest for oil palm plantations, the social problems associated with the displacement of local communities and the destruction of their livelihoods resulting from expanding plantations and with the position of plantation workers, and finally, the health concerns associated with the consumption of palm oil. Most of these criticisms are directed at large scale oil palm plantations in Southeast Asia, despite the presence of a large number of smallholders involved in growing oil palm (Azhar et al., 2017).

These sustainability concerns have made palm oil highly contested in the EU where different societal actors are calling for measures to reduce the negative environmental impacts (Afionis and Stringer, 2012; Barthel et al., 2018; Dauvergne, 2018; Khor, 2011) and driving several palm oil governance initiatives. Global sustainability governance of palm oil is complicated because of the physical distance between consumers and the environmental consequences and because of the 'very high and growing interchangeability of the end uses on palm oil' (Dauvergne, 2018; Pye, 2010). For these reasons, NGO companies and governments have been promoting different initiatives to secure sustainability in palm oil production. Some NGO and consumers are calling for a boycott of palm oil by trying to avoid products containing palm oil (see different actions from Greenpeace and the palm oil free campaigns: http://www.palmolie. info/why-we-are-boycotting-palm-oil/). Other NGO and private companies are promoting the use of (RSPO-certified) sustainably labelled palm oil (see for instance WWF: https://wwf.panda.org/ our_work / food / sustainable_production / palm _ oil/responsible_purchasing/). Some companies, such as Unilever and Nestlé producing consumer products, are aiming to use only $100 \%$ sustainably certified palm oil as input for their food products (https: / / www.unilever.com/sustainable-living/ reducing-environmental-impact/sustainablesourcing/transforming-the-palm-oil-industry / ourapproach-to-sustainable-palm-oil/. The certification strategy has achieved quite some success as in 2017, nearly $80 \%$ of EU palm oil-based food consumption was covered by Roundtable on Sustainable Palm Oil (RSPO)-certified sustainable palm oil (RSPO, 2019). Again other NGO are calling for stricter sustainability standards, and several companies have responded by using 'No deforestation, no peat, no exploitation' (NDPE) palm oil (https:// www.wilmar-international.com/wp-content / uploads / 2012 / 11 / No-Deforestation-No-Peat-NoExploitation-Policy.pdf), (Larsen et al., 2018), and for full traceability of sustainable palm oil. Finally, some financial institutions reconsider investing in oil palm plantations because of the financial and reputational risks involved (Pacheco et al., 2018). Still, as Hinkes (2019) clearly shows there are also actors promoting palm oil as the most sustainable alternative vegetable oil available.

Thus, nowadays palm oil use in the EU occurs in the context of a confusing set of concerns, claims, controversies, policies and strategies, involving policy-makers, NGO, private companies and consumers. In order to make more sense of this situation it is useful to distinguish between arrangements addressing the use of palm oil for biofuels and those dealing with the use of palm oil for non-biofuel purposes and to take a closer look at each of these domains.

\section{PALM OIL USE FOR BIOFUELS IN THE EU}

The EU developed its biofuel policy in order to reduce its fossil fuel use and contribute to climate change mitigation. This policy has gone through several stages for the past 20 years. Initially, the policy started in 1997 with a proposal by the European Commission (EC) for the promotion of renewable energy, including biofuels for transport fuel use (European Commission, 1997). These initial ideas resulted in the so-called Biofuel Directive (2003) which formulated non-binding targets for the blending of biofuels in transport fuels. The blending targets were raised from 2\% in 2005 to $5.75 \%$ in 2010. After several years of implementing this policy, however, the EU concluded that it would not manage to achieve these targets through voluntary measures only and therefore a stricter approach was developed: the Renewable Energy Directive (EU RED-2009/28/EC). The EU RED, covering the period 2010-2020, established a binding target for the EU as a whole which was a $10 \%$ share for sustainable biofuels in road transport fuels by 2020. The objectives of this policy were to secure (European) farmers' incomes, increase energy independence, comply with the Kyoto Protocol, and promote renewable energy (European Commission, 2000). Complying with the Kyoto Protocol was a critical issue in this policy as it required evidence for a reduction in greenhouse gas (GHG) emissions. 
The EC addressed this by formulating the following set of sustainability criteria for biofuels (German and Schoneveld, 2012; Scarlat and Dallemand, 2011):

- GHG savings should be at least 35\% in 2009 increasing to $50 \%$ or $60 \%$ in 2020 ;

- biodiversity should be protected. Therefore, biofuels cannot be produced with feedstock obtained from land with high biodiversity value. This includes land that by or after January 2008 was: (a) primary forest, (b) designated as natural protected area and (c) highly biodiverse grassland;

- biofuels cannot be produced with feedstock obtained from land with high carbon stock. This includes land that by or after January 2008 was: (a) wetland, (b) forest land with a canopy of more than $30 \%$, (c) forest land with a canopy cover between $10 \%$ and $30 \%$, unless specific criteria are fulfilled;

- not from peatlands;

- cultivation practices should follow the requirements for good agricultural practices as specified by the EU; and

- later an additional criterion was added: a maximum of $7 \%$ (of the overall $10 \%$ ) for biofuels produced from food crops.

Biofuels and their feedstock not fulfilling these criteria were not prohibited but they could not be included in the targets set in the EU RED policy. Within the EU, this policy was implemented through national regulations and tax incentives, while for internationally trade private voluntary certification schemes were used. Imported feedstock for biofuels had to be certified through voluntary standards that were recognised by the EU to guarantee the sustainability of a biofuel (ISEAL Alliance, 2017;
Ponte and Daugbjerg, 2015; Stattman et al., 2018). Over the years, several private standards have been recognised (Larsen et al., 2014; Schouten et al., 2012) but some of them have withdrawn after some time, making the landscape of sustainability certification for biofuel feedstock rather confusing (Ponte, 2014; Scarlat and Dallemand, 2011). Nevertheless, most biofuel feedstock is currently certified through the International Sustainability and Carbon Certification (ISCC) scheme (Ponte, 2014) which is considered relatively easily accessible (Hinkes, 2019). Despite all these requirements, biofuel production has grown substantially over the years (Figure 5). As Figure 4 also illustrates, palm oil is the second most important feedstock for biofuel production after rapeseed oil.

Over time, the sustainability criteria included in EU RED became more and more challenged by NGO (Pilgrim and Harvey, 2010) and academics (Skogstad, 2017) and central in this debate were the absence in the policy of GHG-impacts from indirect land use change (ILUC) caused by biofuel feedstock production (Larsen et al., 2014; Searchinger et al., 2008) and the social impacts, especially the consequences for food security (Partzsch, 2011; Ponte, 2014). Some even criticised the basic foundation of this EU biofuel policy because they doubted the actual GHG-savings achieved this way (Hennecke et al., 2013) and questioned the ethics of using food products as feedstock for energy production (Rosegrant and Msangi, 2014). They argued that agricultural land should be used for food production and not for fuel ('food instead of fuel'). Finally, European vegetable oil producers (of rapeseed and sunflower in Sweden, Germany and France) claimed that their products should be preferred above imported vegetable oils (Firrisa et al., 2014).

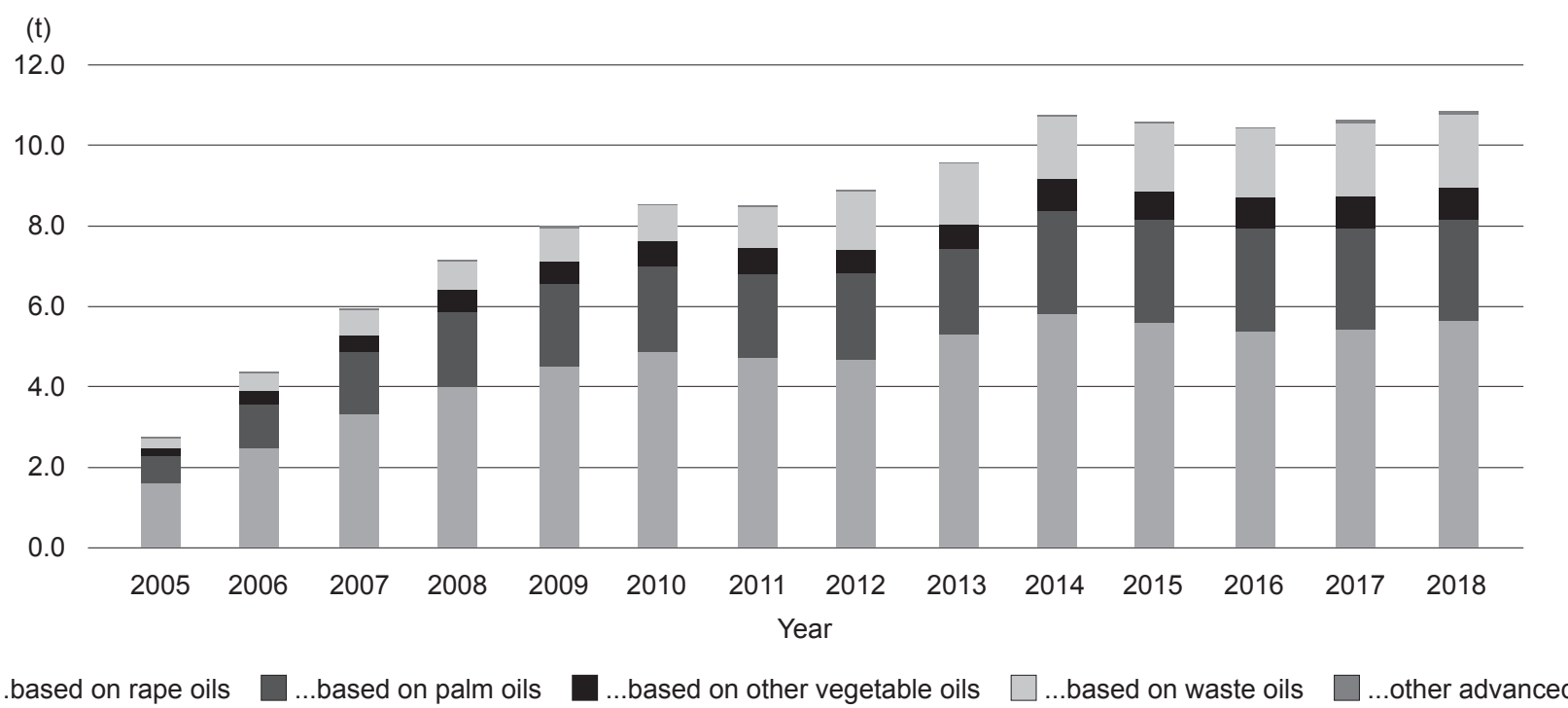

Source: European Commission (2018).

Figure 5. European Union (EU) biofuel production (million tonnes oil equivalents). 
Palm oil was targeted in this debate as palm oil-based biofuels were accused of being 'imported deforestation', because increasing palm oil production is expected to cause further deforestation (Pehnelt and Vietze, 2013). In January 2018, the European Parliament passed a resolution requesting the EC to phase out the use of palm oil as a feedstock for the production of biofuels by 2021 (European Parliament, 2018a). In November 2018, the French National Assembly passed a bill explicitly stating that palm oil 'is not a biofuel' and that tax advantages benefitting agro-fuels derived from palm oil should be ended by 2020. The Norwegian Parliament (December 2018) requested the government to develop measures to avoid high deforestation risk biofuels, hereby referring to deforestation caused by palm oil as a major concern.

These comments and criticisms generated a continuous debate on biofuel policies within the EU since the early 2010s (Bürgin, 2015). So, when the policy had to be renewed towards 2020, it was not surprising that sustainability criteria became even more strict and the use of agricultural products, including palm oil, as feedstock for biofuels even more limited.

EU RED II was proposed in 2018 (European Parliament, 2018b) as a renewed policy framework to cover the period 2021-2030, within which the target for the first generation biofuels (i.e. agricultural feedstock based) was lowered to $7 \%$ (down from $10 \%$ ). To achieve this policy goal, tax incentives could be introduced (varying per country) and quota measures be set while sustainability standards needed to be adhered to. The existing sustainability requirements from the first RED were maintained and some were substantially tightened such as the requirements for GHG-savings, now being set at $65 \%$ after 2021. As a particular innovation, a distinction between high- and low-risk ILUC biofuels was introduced. High-risk ILUC biofuels were considered those produced from feedstock for which a significant expansion of the production area into land with high carbon stock had been observed (European Commission, 2019b). High ILUC-risk biofuels would need to freeze at 2019 levels and be phased-out by 2030, unless specific batches could be certified as 'low indirect land-use change risk'. In the operationalisation of this criterion, the European Commission (2019b) stated that the expansion into high carbon forest for palm oil was calculated as 45\% and for soyabean oil only 9\% (European Commission, 2019a). Palm oil was therefore considered a high-risk ILUC biofuel feedstock.

The revised REDII was criticised by the palm oil industry because it was seen as unfair discrimination against palm oil (Hinkes, 2019; Subramaniam et al., 2019), while implementing the policy would have unintended consequences through the increased use of other feedstock with potentially larger environmental impacts (Hinkes, 2019). Other arguments brought forward by Indonesia and Malaysia were the accusation of 'green neocolonialism' and the use of sustainability concerns as a pretext for defending the interests of European agro-industry. Malaysia even called the new policy 'crop apartheid' (Reuters, 2018). The European farmers were mainly concerned about the continued use of palm oil (COPA-COGECA, 2019) despite the introduction of ILUC criteria and suggested even stricter measures to avoid palm oil.

This overview illustrates how biofuels are becoming highly controversial in the EU and how over time the sustainability issues included in the official policies have been narrowed down from an initially broad range of issues to finally ILUC as the central criterion in REDII (Koning, 2019). It is therefore understandable that among the biofuels, palm oil is targeted because of its ILUCrisk. However, explicitly excluding palm oil is legally highly complicated because this would not be in accordance with the World Trade Organisation (WTO) requirements (Daugbjerg and Swinbank, 2015). Therefore, particular standards and criteria are being applied that may in effect exclude (or at least limit) the use of palm oil while not targeting palm oil explicitly. WTO regulations have played a role in two anti-dumping cases that the EU pursued in 2013 via the WTO against (soyabean-based) biodiesel from Argentina (DS473) and (palm oil-based) biodiesel from Indonesia (DS480) (USDA, 2018) to which both countries complained. The WTO Dispute Panel concluded that the EU was not allowed to take these measures and the anti-dumping duties were lifted in 2018. When developing REDII the EU therefore took care not to target specific feedstocks but to formulate general sustainability criteria.

\section{PALM OIL USE FOR NON-BIOFUEL PURPOSES IN THE EU}

Before the promotion of biofuels, the EU already imported palm oil for other uses, because of its availability, versatility in applications and its relatively low price. In recent years, this trade has come under pressure of the same public concerns mentioned before. The debate with respect to governing the use of palm oil for nonbiofuel purposes, however, has several different characteristics.

An important regulatory change in the EU for the use of palm oil in food is Regulation 1169/2011 on the Provision of Food Information to Consumers (Novelli, 2016). This regulation required the manufacturers of vegetable oil containing products to indicate the category of vegetable oils they use on the list of product ingredients and no longer use the general category of 'vegetable oil'. As most palm oil 
in Europe is not used as cooking oil but processed into a large range of different food and non-food products, it was only through this information that consumers were given the opportunity to select a product on the basis of its vegetable oil composition. The introduction of this regulation also proved an incentive for manufacturers to either substitute palm oil by a less controversial alternative or to choose certified palm oil in order to avoid consumer or NGO criticisms (Ruggeri and Samoggia, 2018). For this reason, companies such as Unilever, Nestlé and Procter \& Gamble, expressed they intend to only use traceable certified palm oil. This way they tried to protect their business reputation and this is also why their main concern is to avoid using palm oil that can be connected to deforestation which is the central issue in the public debate.

Contrary to biofuels, the EU has no formal sustainability requirements for palm oil imported for food and non-food processing purposes, other than general product import and specific food safety requirements. The use of palm oil for food and non-food processing purpose is without legal limitations. There are, nevertheless, intense debates on the sustainability of palm oil (Corciolani et al., 2019) and voluntary private schemes promoting the sustainability of palm oil have been introduced with the RSPO being the most important one among them. The RSPO offers manufacturers the possibility to make use of certified sustainable palm oil. The RSPO was founded in 2004 as a voluntary membership association of investors, growers, processing firms and NGO to promote economic, social and environmental sustainability in the production and use of palm oil (Oosterveer, 2015; Von Geibler, 2013). Private certification is justified through a narrative of deficient states (Schouten and Hospes, 2018) and the more effective use of market mechanisms in global environmental governance (Cashore et al., 2004). The RSPO has developed a third party-based certification standard for sustainable palm oil (Brandi et al., 2015) and since its start in 2007, the growth has been considerable with nearly 3.2 million hectares of plantation areas and nearly 140000 smallholders being certified in 2018 (RSPO, 2019). In most instances, RSPO-certified products are not supplied with a consumer-facing label which means that certification is mainly used as a B2B tool rather than as a tool aiming at direct consumer engagement. Still, the RSPO remains contested in the several respects.

First, the legitimacy of the RSPO is questioned, particularly with respect to the central role of large (mainly European) private companies in the organisation which raises fears for being 'greenwashed' (Dauvergne, 2018; Pichler, 2013; Von Geibler, 2013). There is 'a reoccurring critique that RSPO is used by companies to 'legalise' deforestation and unsustainable practices by palm oil producing companies (Von Geibler, 2013). On this basis, the sustainability of RSPO-certified palm oil is repeatedly challenged (Pye, 2019).

Second, observers question the impact of the RSPO and they doubt whether RSPO certification will achieve better outcomes than 'business as usual' (Cazzolla Gatti et al., 2018). A particular issue is the limited market share of RSPO-certified palm oil on the global market (Bentivoglio et al., 2018b).

Third, the RSPO seems primarily accountable to the members involved (Henriksen, 2015) and to the consumers in Europe and the US. However, accountability to local stakeholders in the production countries is arguably less developed (Higgins and Richards, 2019; Larsen et al., 2014). For instance, the RSPO does not take responsibility for the actual sale of certified sustainable palm oil which makes growers dependent on uncertain markets to cover the costs involved in certification.

Fourth and final, the RSPO is competing with other sustainability standards such as the Indonesian Initiative for Sustainable Palm Oil (ISPO) and the Malaysian Sustainable Palm Oil (MSPO) certification schemes (Higgins and Richards, 2019; Hospes, 2014; Schouten and Hospes, 2018), which rely on national government regulations and not on voluntary participation like the RSPO. The ISPO and MSPO are, however, hardly recognised within the EU also because they are mandatory for all oil palm growers in their respective countries while they do not distinguish between more and less sustainable production practices (Dauvergne, 2018). At the same time, as Von Geibler (2013) argues, the presence of multiple standards contributes to confusion among producers, manufacturers and consumers.

\section{ANALYSIS AND DISCUSSION}

The public and policy debate on palm oil used as feedstock for biofuels should be distinguished from the debate on palm oil used for food and other usages. The market of biofuels is completely dependent on EU regulations. The EU biofuel policy sets clear targets for the use of biofuels and strict criteria for the sustainable use of vegetable oil as feedstock (Stattman et al., 2018). Without this policy, there would be no market for biofuels in the EU and therefore no demand for feedstock such as palm oil. The use of palm oil for biofuel production and use therefore depends on political decisions. The use of palm oil for food and other purposes, on the other hand, is largely left to market dynamics with little political involvement, except for general food and food safety requirements. However, the controversial character of palm oil-based biofuels leads to a more general criticism on utilising palm oil without making much difference with respect 


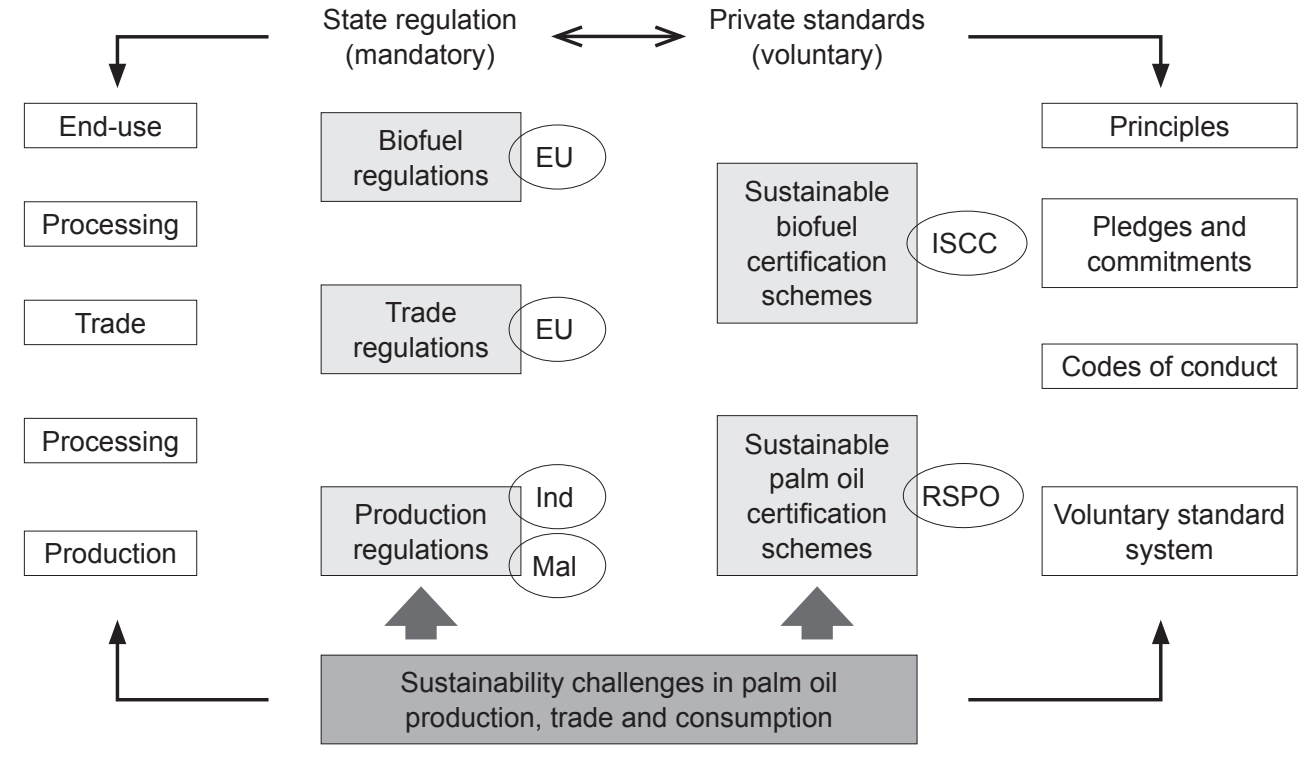

Note: Mal - Malaysia.

Ind - Indonesia.

EU - European Union.

ISCC - Initiative for Sustainable Palm Oil.

RSPO - Roundtable on Sustainable Palm Oil.

Source: Pacheco et al. (2018).

Figure 6. The palm oil sustainability governance landscape.

to its actual use. Figure 6 summarised an overview of the various governance arrangements for palm oil and the role of public and private initiatives to clarify the distinction between palm oil-based biofuel governance and governance of other palm oil usages.

As explained by Pacheco et al. (2018), the governance of palm oil production and use constitutes a complex landscape where public and private arrangements function next to each other and where different uses overlap. Nevertheless, two key sustainability governance arrangements come to the fore. First, the government (EU)-dominated biofuels regulation supported by voluntary certification schemes and second, the voluntary certification (RSPO)-dominated arrangement for palm oil trade for food to the EU.

Political debates on the first arrangement are highly relevant for palm oil producing countries because they may have immediate impacts on the opportunities for producing countries to export palm oil for this use. The present debate within the EU seems to point at a termination of the use of vegetable oil for conventional biofuels in the near future whereby palm oil is targeted as the first feedstock to be phased out. EU biofuels policies are currently dominated by the need to contribute effectively to the reduction of GHG emissions. As a consequence, the use of vegetable oils is coming to an end mainly because the sustainability standard used is shifting. Under REDI, the sustainability of a feedstock offered as input for biofuel production was based on the fulfilment of a particular set of technical indicators for that particular feedstock, developed and implemented by private governance actors. However, under REDII, sustainability of a feedstock is primarily based on the ILUC performance of the agricultural crop concerned and therefore a rather political definition of sustainability. This observation confirms the conclusion by Schouten et al. (2012) that tensions exist between public and private regulatory systems in the case of biofuels because of their specific dynamics and that in this tension the question whether a sustainability standard is only a set of technical indicators that have to be measured or whether it also involves a public debate on what sustainable biofuels actually are, plays a crucial role.

The debate on the second governance arrangement is even more confusing because there is no obvious target. EU policies only indirectly influence the use of palm oil for food and other industrial uses and most is left to market dynamics because it is considered a commodity which trade and use should be arranged through the market mechanism like other commodities. Considering the obligations within WTO agreement, it is highly unlikely that the EU or any of its member states will intervene in palm oil trade for this use. Among the WTO principles, the promotion of international trade and respect for other country's 'sovereignty', prevent such interference (Oosterveer, 2015). 
In this case, the debate is much more a public debate involving manufacturers, NGO and consumers and much less a debate in political institutions. Much of this debate takes place in public and social media.

Nevertheless, this debate may have substantial consequences for imports and use of palm oil and thus for the position of palm oil producing countries. The call for palm oil sustainability means a call for cross-border collaboration and international coordination (Schouten and Hospes, 2018) and for involving private as well as public actors. The focus of the debate is on the definition of sustainable palm oil and on the question whether global standards should be preferred above national standards. The debate is not only technical but also political when it addresses global versus national and present versus future interests. Engaging with this debate is important for producer countries because it directly influences their future export opportunities. Participating in the debate means more than solely distributing information about palm oil production practices because they should also engage with the framings that dominate the debate. Nevertheless, it remains relevant to explain what actual measures have been taken to assure the sustainability of palm oil and how their implementation has been monitored. Critical for the influence producer countries may have on the public debates in the EU is transparency about the measures taken to secure sustainability and their actual impacts as well as about the measures taken by the industry.

\section{CONCLUSION}

In this article, I have shown that concerns about the sustainability of palm oil are deeply rooted in the EU, widespread and intensify over time. Palm oil producing countries interested in engaging with this debate in the EU should be aware that this requires in-depth understanding of background and content of the debate in order to be effective. One important conclusion from the overview of the debate presented in this article is that the dynamics in the debate on palm oil used for biofuels differ from palm oil used for other purposes. The debate on palm oil-based biofuels is dominated by the official regulations of the EU because the biofuels market is to a high level under governmental control. We observed a gradual withdrawal of policy support for conventional biofuels which reduces the future opportunities for palm oil as a feedstock imported to the EU. The use of palm oil in other markets is, however, much less steered by the EU authorities because they are only partly under governmental control and in these markets private sustainability schemes and NGO campaigns are actually leading the innovations in governance arrangements and they are only incidentally supported by governments.
Producing countries may engage with these debates on governing palm oil but to be effective they need to ascertain their legitimacy and accountability in doing so. Being seen as legitimate in the public debate on sustainable palm oil requires the recognition of a global perspective on how to define sustainability, thereby going beyond a national perspective. This includes the acceptance of private initiatives as potential contributions to palm oil sustainability governance. Being seen as accountable also requires being transparent, i.e. willing to share verifiable information about the actual measures taken and their impact. Addressing these conditions would increase the likelihood of an effective participation of palm oil producing countries in the debate in the EU on sustainable palm oil, making this policy debate more legitimate and probably also more effective.

\section{REFERENCES}

Afionis, S and Stringer, L C (2012). European Union leadership in biofuels regulation: Europe as a normative power? J. Cleaner Production, 32(0): 114123.

Aguiar, L K; Martinez, D C and Caleman, S M Q (2018). Consumer awareness of palm oil as an ingredient in food and non-food products. J. Food Products Marketing, 24(3): 297-310. DOI:10.1080/1045 4446.2017.1266559.

Austin, K G; Schwantes, A; Gu, Y and Kasibhatla, P S (2019). What causes deforestation in Indonesia? Environmental Research Letters, 14(2): 024007. DOI:10.1088/1748-9326/ aaf6db.

Azhar, B; Saadun, N; Prideaux, M and Lindenmayer, D B (2017). The global palm oil sector must change to save biodiversity and improve food security in the tropics. J. Environmental Management, 203(Part 1): 457466. DOI:https:// doi.org/10.1016/j.jenvman.2017. 08.021 .

Barthel, M; Jennings, S; Schreiber, W; Sheane, R; Royston, S; Fry, J and McGill, J (2018). Study on the Environmental Impact of Palm Oil Consumption and on Existing Sustainability Standards. 396 pp.

Bentivoglio, D; Finco, A and Bucci, G (2018a). Factors affecting the Indonesian palm oil market in food and fuel industry: Evidence from a time series analysis. International J. Energy Economics and Policy, 8(5): 49-57.

Bentivoglio, D; Finco, A; Bucci, G and Zolin, M B (2018b). Asian palm oil production and European vegetable oil market: What can we learn in terms of sustainability. Asian Nations and Multinationals: 
Overcoming the Limits to Growth (AndreossoO'Callaghan, B; Jaussaud, J and Zolin, M B eds). Cham: Palgrave MacMillan. p. 83-101.

Brandi, C; Cabani, T; Hosang, C; Schirmbeck, S; Westermann, L and Wiese, H (2015). Sustainability standards for palm oil: Challenges for smallholder certification under the RSPO. The J. Environment and Development, 24(3): 292-314. DOI:10.1177/ 1070496515593775.

Bürgin, A (2015). National binding renewable energy targets for 2020, but not for 2030 anymore: Why the European Commission developed from a supporter to a brakeman. J. European Public Policy, 22(5): 690-707.

Cashore, B W; Auld, G and Newsom, D (2004). Governing through Markets: Forest Certification and the Emergence of Non-state Authority. New Haven: Yale University Press. 352 pp.

Cazzolla Gatti, R; Liang, J; Velichevskaya, A and Zhou, M (2019). Sustainable palm oil may not be so sustainable. Science of the Total Environment, 652:48-51. DOI:https: / / doi.org/10.1016/j.scitotenv.2018.10. 222.

Copenhagen Economics (2018). EU imports of palm oil from Indonesia, Malaysia and Thailand. Copenhagen Economics. 2 pp.

COPA-COGECA (2019). RED II implementation - Copa and Cogeca concerns about loopholes in 'low ILUC' palm oil confirmed (Press release, 15 February 2019).

Corciolani, M; Gistri, G and Pace, S (2019). Legitimacy struggles in palm oil controversies: An institutional perspective. J. Cleaner Production, 212: 1117-1131.

Daugbjerg, C and Swinbank, A (2015). Globalization and new policy concerns: The WTO and the EU's sustainability criteria for biofuels. J. European Public Policy, 22(3): 429-446. DOI:10.1080/13501763.2014.9 27520.

Dauvergne, P (2018). The global politics of the business of 'sustainable' palm oil. Global Environmental Politics, 18(2): 34-52. DOI:10.1162/ glep_a_00455.

European Commission (2019a). Report from the Commission to the European Parliament, the Council, the European Economic and Social Committee and the Committee of the Regions on the Status of Production Expansion of Relevant Food and Feed Crops Worldwide. 20 pp.
European Commission (2019b). Report on the Status of Production Expansion of Relevant Food and Feed Crops Worldwide [COM(2019) 142 final]. 20 pp.

European Commission (2018). EU Agricultural Outlook for Markets and Income 2018-2030. 128 pp.

European Parliament (2018a). Amendments Adopted by the European Parliament on 17 January 2018 on the Proposal for a Directive of the European Parliament and of the Council on the Promotion of the Use of Energy from Renewable Sources (recast). 161 pp.

European Parliament (2018b). Directive (EU) 2018/2001 of the European Parliament and of the Council of 11 December 2018 on the Promotion of Energy from Renewable Sources. 161 pp.

European Commission (2000). Green Paper - Towards a European Strategy for the Security of Energy Supply. 90 pp.

European Commission (1997). Energy for the Future: Renewable Sources of Energy. White Paper for a Community Strategy and Action Plan. 68 pp.

Fediol (2019). Vegetable oils production, imports, exports and consumption. https:/ / www.fediol. eu / data / 1536657034Stat\%20oils\%20evolution.pdf, accessed on 4 August 2019.

Firrisa, M T; Van Duren, I and Voinov, A (2014). Energy efficiency for rapeseed biodiesel production in different farming systems. Energy Efficiency, 7(1): 79-95. DOI:10.1007/s12053-013-9201-2.

German, L and Schoneveld, G (2012). A review of social sustainability considerations among EUapproved voluntary schemes for biofuels, with implications for rural livelihoods. Energy Policy, 51: 765-778.

Hennecke, A M; Faist, M; Reinhardt, J; Junquera, V; Neeft, J and Fehrenbach, H (2013). Biofuel greenhouse gas calculations under the European Renewable Energy Directive - A comparison of the BioGrace tool vs. the tool of the Roundtable on Sustainable Biofuels. Applied Energy, 102: 55-62. DOI: https: //doi.org/10.1016/j.apenergy. 2012.04.020.

Henriksen, L F (2015). The global network of biofuel sustainability standards-setters. Environmental Politics, 24(1): 115-137. DOI:10.1080/09644016.2014. 955680.

Higgins, V and Richards, C (2019). Framing sustainability: Alternative standards schemes for sustainable palm oil and South-South trade. J. Rural 
Studies, 65: 126-134. DOI:https:/ / doi.org/10.1016/j. jrurstud.2018.11.001.

Hinkes, C (2019). Adding (bio)fuel to the fire: Discourses on palm oil sustainability in the context of European policy development. Environment, Development and Sustainability. DOI:10.1007/s10668019-00541-y.

Hospes, O (2014). Marking the success or end of global multi-stakeholder governance? The rise of national sustainability standards in Indonesia and Brazil for palm oil and soy. Agriculture and Human Values, 31: 425-437. DOI:10.1007/s10460-014-9511-9.

ISEAL Alliance (2017). Private Sustainability Standards and the EU Renewable Energy Directive. 3 pp.

Khor, Y L (2011). The oil palm industry bows to NGO campaigns. Lipid Technology, 23(5): 102-104.

Koning, E (2019). Palm Oil: Biofuels' Broken Promise. The Status of Palm Oil in the Sustainability Framework of the EU Biofuel Policy. B.Sc. thesis. Wageningen University, Wageningen, The Netherlands.

Larsen, R K; Jiwan, N; Rompas, A; Jenito, J; Osbeck, M and Tarigan, A (2014). Towards 'hybrid accountability' in EU biofuels policy? Community grievances and competing water claims in the Central Kalimantan oil palm sector. Geoforum, 54(Supplement C): 295-305. DOI:https://doi. org/10.1016/j.geoforum.2013.09.010.

Larsen, R K; Osbeck, M; Dawkins, E; Tuhkanen, H; Nguyen, H; Nugroho, A and Wolvekamp, P (2018). Hybrid governance in agricultural commodity chains: Insights from implementation of 'No Deforestation, No Peat, No Exploitation'(NDPE) policies in the oil palm industry. J. Cleaner Production, 183: 544-554.

Mielke, T (2018). World markets for vegetable oils and animal fats. Biokerosene: Status and Prospects (Kaltschmitt, M and Neuling, U eds.). Berlin, Heidelberg: Springer. p. 147-188.

Morgans, C L; Meijaard, E; Santika, T; Law, E; Budiharta, S; Ancrenaz, M and Wilson, K A (2018). Evaluating the effectiveness of palm oil certification in delivering multiple sustainability objectives. Environmental Research Letters, 13(6): 064032. DOI:10.1088/1748-9326/ aac6f4.

Novelli, E (2016). Sustainability as a success factor for palm oil producers supplying the European vegetable oil markets. Oil Palm Industry Economic J. Vol. 16(1): 8-17.
Oosterveer, P (2015). Promoting sustainable palm oil: Viewed from a global networks and flows perspective. J. Cleaner Production, 107: 146-153. DOI:http:/ / dx.doi.org/10.1016/j.jclepro.2014.01.019.

Pacheco, P; Schoneveld, G; Dermawan, A; Komarudin, H and Djama, M (2018). Governing sustainable palm oil supply: Disconnects, complementarities, and antagonisms between state regulations and private standards. Regulation $\mathcal{E}$ Governance, 14(3): 568-598. DOI:10.1111 / rego.12220.

Partzsch, L (2011). The legitimacy of biofuel certification. Agriculture and Human Values, 28(3): 413-425. DOI:10.1007/s10460-009-9235-4.

Pehnelt, G and Vietze, C (2013). Recalculating GHG emissions saving of palm oil biodiesel. Environment, Development and Sustainability, 15(2): 429-479.

Pichler, M (2013). People, planet \& profit: Consumer-oriented hegemony and power relations in palm oil and agrofuel certification. The J. Environment \& Development, 22(4): 370-390. DOI: $10.1177 / 1070496513502967$.

Pilgrim, S and Harvey, M (2010). Battles over biofuels in Europe: NGOs and the politics of markets. Sociological Research Online, 15(3): 1-16.

Ponte, S (2014). 'Roundtabling' sustainability: Lessons from the biofuel industry. Geoforum, 54: 261-271. DOI:http://dx.doi.org/10.1016/j. geoforum.2013.07.008.

Ponte, S and Daugbjerg, C (2015). Biofuel sustainability and the formation of transnational hybrid governance. Environmental Politics, 24(1): 96114.

Pye, O (2010). The biofuel connection - Transnational activism and the palm oil boom. J. Peasant Studies, 37(4): 851-874.

Pye, O (2019). Commodifying sustainability: Development, nature and politics in the palm oil industry. World Development, 121: 218-228. DOI: https:/ / doi.org/10.1016/j.worlddev.2018.02.014.

Reuters (2018). European move to ban palm oil from biofuels is 'crop apartheid' - Malaysia. https:// www.reuters.com/article/malaysia-palmoil-eu / european-move-to-ban-palm-oil-from-biofuels-iscrop-apartheid-malaysia-idUSL3N1PD1NJ

Rosegrant, M W and Msangi, S (2014). Consensus and contention in the food-versus-fuel debate. Annual Review of Environment and Resources, 39(1): 271-294. DOI:10.1146/ annurev-environ-031813-132233. 
RSPO (2019). RSPO Impact Report 2018.86 pp.

Ruggeri, A and Samoggia, A (2018). Twitter communication of agri-food chain actors on palm oil environmental, socio-economic, and health sustainability. J. Consumer Behaviour, 17(1): 75-93. DOI:10.1002/cb.1699.

Scarlat, N and Dallemand, J-F (2011). Recent developments of biofuels/bioenergy sustainability certification: A global overview. Energy Policy, 39(3): 1630-1646. DOI:https:// doi.org/10.1016/j. enpol.2010.12.039.

Schouten, G and Glasbergen, P (2012). Private multistakeholder governance in the agricultural market place: An analysis of legitimization processes of the Roundtable on Sustainable Palm Oil and Responsible Soy. International Food and Agribusiness Management Review (IFAMA), 15(Special Issue B): 6388.

Schouten, G and Hospes, O (2018). Public and private governance in interaction: Changing interpretations of sovereignty in the field of sustainable palm oil. Sustainability, 10(12): 4811.

Schouten, G; Leroy, P and Glasbergen, P (2012). On the deliberative capacity of private multistakeholder governance: The Roundtables on Responsible Soy and Sustainable Palm Oil. Ecological Economics, 83: 42-50.
Searchinger, T; Heimlich, R; Houghton, R A; Dong, F; Elobeid, A; Fabiosa, J and Yu, T-H (2008). Use of US croplands for biofuels increases greenhouse gases through emissions from land-use change. Science, 319(5867): 1238-1240.

Skogstad, G (2017). Policy feedback and selfreinforcing and self-undermining processes in EU biofuels policy. J. European Public Policy, 24(1): 21-41.

Stattman, S L; Gupta, A; Partzsch, L and Oosterveer, P (2018). Toward sustainable biofuels in the European Union? Lessons from a decade of hybrid biofuel governance. Sustainability, 10(11): 4111.

Subramaniam, V; Kuntom, A; Zainal, H; Loh, S K; Aziz, A A and Parveez, G K A (2019). Analysis of the uncertainties of the inclusion of indirect land use change into the European Union Renewable Energy Sources Directive II. J. Oil Palm Res. Vol. 31(3): 480-488.

USDA (US Department of Agriculture) (2018). GAIN Report: EU-28 Biofuels Annual 2018. 52 pp.

USDA (US Department of Agriculture) (2019). Oilseeds: World Markets and Trade, USDA-FAC. 38 pp.

Von Geibler, J (2013). Market-based governance for sustainability in value chains: Conditions for successful standard setting in the palm oil sector. $J$. Cleaner Production, 56(1): 39-53. DOI:http:/ / dx.doi. org/10.1016/j.jclepro.2012.08.027. 